\title{
Taloudellinen demokratia ja kapitalismin kritiikki historiallisina ilmiöinä
}

\section{ILKKA KÄRRYLÄ}

Kylmän sodan päätyttyä moni katsoi, että kapitalismi oli osoittautunut ainoaksi toimivaksi talousjärjestelmäksi. Vuoden 2008 finanssikriisin jälkeen kritiikki kapitalismia kohtaan on kuitenkin vähitellen yltynyt. Kapitalismia syytetään kriisiherkkyydestä, kyvyttömyydestä hillitä ilmastonmuutosta sekä taipumuksesta kasata vaurautta jo valmiiksi varakkaimmille. Länsimaissa myös investoinnit ja tuottavuuskasvu ovat viimeisen vuosikymmenen ajan olleet heikkoja aiempaan verrattuna.

Syksyllä 2019 kapitalismin kritiikki voimistui myös liike-elämän piirissä. Yhdysvaltalaisten yritysjohtajien foorumi Business Roundtable linjasi, että yritysten tulee ottaa tehtäväkseen kaikkien sidosryhmien hyödyttäminen sen sijaan, että päätehtävänä olisi tuottaa voittoa osakkeenomistajille. Myös sanomalehti Financial Times vetosi vahvasti kapitalismin uudistamisen puolesta. Päätoimittaja Lionel Barber muistutti kirjoituksessaan vapaan kapitalismin tuottamasta rauhasta, vauraudesta ja teknologisesta kehityksestä, mutta totesi myös tarpeen uudistua:

[...] globaalia finanssikriisiä seuranneen vuosikymmenen aikana tämä malli [vapaa kapitalismi], erityisesti keskittyminen voittojen ja osakkeiden arvon maksimointiin, on joutunut koetukselle. Nämä hyvän liiketoiminnan periaatteet ovat välttämättömiä mutta eivät riittäviä. Vapaaseen yrittäjyyteen perustuva kapitalismi on osoittanut huomattavaa uudistumiskykyä. Toisinaan [...] on välttämätöntä uudistua selviytyäkseen. Nyt se hetki on käsillä. On uudelleenkäynnistyksen aika. (Financial Times 16.9.2019, suom. I.K.)

Vaikutusvaltainen lausunto vannoutuneelta vapaan kapitalismin puolustajalta osoittaa, että uudistuksia pohditaan laajalla rintamalla. Samanlaisia vaatimuksia on kuitenkin esitetty lukuisia kertoja historian aikana poliittisen kentän eri puolilta. Seuraavassa esimerkissä tilannekuva on hyvin samankaltainen, ja uudistuksen suuntaakin hahmotellaan:

Nykyinen taloudellinen lama koko kapitalistisessa maailmassa osoittaa vastaansanomattomasti, että markkinatalous ei enää kykene tyydyttävästi ohjaamaan talouselämän kulkua eikä laajentamaan sen pohjaa kehitysedellytyksiä vastaavalla tavalla. [...] Hyvinvoinnin tasapainoisen kasvun turvaaminen edellyttää, että taloudellista kansanvaltaa laajennetaan. Yhteiskunnan on vastuun lisäksi saatava myös valtaa suunnitella ja ohjata taloudellista kehitystä. Vain siten voidaan torjua ennalta lamat ja kriisit. (SDP 1975)

Lainaus on peräisin Suomen Sosialidemokraattisen Puolueen (SDP) vuoden 1975 puoluekokouksessaan tekemästä julkilausumasta. Se osoittaa, että kapitalismin katsottiin olevan uudistamisen tarpeessa myös 45 vuotta sitten. 
Pian julkilausuman jälkeen kapitalismi uudistuikin merkittävästi. Uudistukset eivät kuitenkaan onnistuneet erityisen hyvin taantumien ja kriisien ehkäisemisessä tai hyvinvoinnin tasapainoisessa kasvattamisessa. 1970-luvulta alkaen pääomalle annettiin poliittisin päätöksin lisää vapautta etsiä voittoja eri puolilta maailmaa, mikä on johtanut aiempaa vakavampiin talouskriiseihin (Streeck 2015). SDP:n julkilausuma nimesi sitä vastoin "taloudellisen kansanvallan” edellytykseksi suotuisalle kehitykselle. Miksi tämä käsite on kadonnut poliittisesta kielestä, ja miksi kaikissa länsimaissa siirryttiin säännellystä vapaampaan kapitalismiin pian vuoden 1975 jälkeen?

Kysymykseen vastaamiseksi on palattava ajassa hieman kauemmas taaksepäin katsomaan, mistä taloudellisessa kansanvallassa tai demokratiassa oikeastaan oli kyse. Tarkastelen seuraavassa erityisesti väitöskirjassani (Kärrylä 2019) analysoituja keskusteluja Suomessa ja Ruotsissa.

\section{UNELMA DEMOKRAATTISESTA TALOUDESTA}

Talouden ja työelämän demokratisointi olivat merkittäviä poliittisia tavoitteita useimmissa länsimaissa läpi 1900-luvun. Erityisesti Pohjoismaissa taloudellinen demokratia oli näkyvä käsite poliittisissa ohjelmissa ja keskusteluissa. Se oli keskeinen vasemmistopuolueille ja ammattiliitoille, mutta myös keskusta ja oikeisto sekä liike-elämän edustajat kehittivät omia visioitaan demokraattisemmasta taloudesta.

Keskustelua taloudellisesta demokratiasta käytiin kolmessa aallossa: molempien maailmansotien jälkeen 1920- ja 1940-luvuilla sekä jälleen 1960-1970-luvuilla erityisesti vasemmistolaisen radikalismin innoittamana. Teeman nousu poliittiselle agendalle liittyi yhteiskunnallisen epävarmuuden hetkiin, jolloin radikaalitkin muutosvaatimukset tulivat mahdollisiksi.

Toisen maailmansodan jälkeen demokratiasta tuli universaalisti hyväksytty hallitusmuoto ja poliittista valtaa legitimoiva käsite (Dunn 2005). Demokratian laajentamista uusille elämänaloille pidettiin luonnollisena kehityksenä, ja taloudellisen demokratian perusmerkityksestä vallitsi laaja yksimielisyys: se tarkoitti taloudellisen vallan jakamista entistä tasaisemmin kaikille kansalaisille. Eri ryhmät esittivät kuitenkin hyvin erilaisia näkemyksiä tämän abstraktin periaatteen toteuttamiseksi omien ideologioidensa mukaisesti. Taloudellisen demokratian ja sen naapurikäsitteiden, kuten teollisen demokratian ja yritysdemokratian, merkityksestä kiisteltiin siksi erittäin voimakkaasti.

Suomalaisten ja ruotsalaisten vasemmistopuolueiden esittämissä näkemyksissä taloudellinen demokratia oli vahvasti tulevaisuuteen suuntautunut käsite ja läheisessä yhteydessä kehityksen ja modernisaation aatteisiin. 1920-luvulta alkaen pohjoismaiset sosiaalidemokraatit esittivät demokratian laajentamisen lineaarisena kolmivaiheisena prosessina. Poliittinen demokratia, eli yleinen ja yhtäläinen äänioikeus sekä parlamentin luottamusta nauttiva hallitus, oli vasta kehityksen ensimmäinen askel. Tämän jälkeen oli toteutettava sosiaalinen demokratia eli yhtäläiset sosiaaliset oikeudet ja julkiset palvelut kaikille kansalaisille. Taloudellinen demokratia oli kolmas ja viimeinen vaihe matkalla kohti hyvää yhteiskuntaa (Friberg 2012).

Vasemmiston ajattelussa taloudellinen demokratia yhdistettiin talouden suunnitteluun ja toisinaan jopa tuotantovälineiden sosialisointiin. Vuosikymmenien ajan siirtyminen sosialismiin oli varteenotettava vaihtoehto pelkälle kapitalismin uudistamiselle. Vaihtoehdoista käytiin tunnetusti kovaa kamppailua myös vasemmiston sisällä, erityisesti sosiaalidemokraattien ja 
kommunistien välillä. Maltillisemmissa muodoissa taloudellinen demokratia merkitsi työntekijöiden vallan kasvattamista yrityksissä, voittojen ja omistuksen jakamista sekä kansantalouden "demokraattista ohjailua".

Keskusta- ja oikeistopuolueet sekä monet liike-elämän edustajat tahtoivat niin ikään viedä kapitalismia kohti taloudellista demokratiaa. Nämä ryhmät eivät kuitenkaan hyväksyneet valtion taloudellisen roolin merkittävää kasvattamista tai omistamisen kollektivisointia. Sen sijaan ne tavoittelivat hajautettua demokratiaa, joka perustuisi markkinatalouteen, yksityisomistukseen, kansalaisten vapaaehtoisiin yhteenliittymiin ja pohjoismaiseen paikallisen itsehallinnon perinteeseen. Liike-elämälle ja porvaripuolueille taloudellinen demokratia merkitsi erityisesti yksityisomistuksen ja osakesäästämisen laajentamista kansalaisten parissa. Suomen Kokoomus ja Ruotsin oikeistopuolue Högerpartiet (myöh. Moderata samlingspartiet) kutsuivat mallejaan anglosaksisista maista omaksutuin käsittein "kansankapitalismiksi" ja "omistajademokratiaksi". Käsitteiden käytön selvänä tavoitteena oli valjastaa vasemmistolainen demokratian laajentamisen retoriikka omaan käyttöön.

Porvaripuolueet ja liike-elämä kannattivat myös demokratian laajentamista työpaikoille lisäämällä neuvoa-antavaa yhteistoimintaa johtajien ja työntekijöiden välillä. Kuten tänä päivänäkin, korostettiin kaikkien sidosryhmien tavoitteiden huomioimista pelkkien osakkeenomistajien sijaan. Demokratian käsitteen mainitsemista näissä yhteyksissä kuitenkin välteltiin. Puhumalla yhteistoiminnasta porvarit ja liike-elämä esittivät taloudellisen toiminnan harmonisena, epäpoliittisena ja vailla eturistiriitoja. Hyväksyttyjä demokratisoinnin muotoja rajattiin vetoamalla yritysten tehokkuuteen, jonka ylläpitämisen todettiin olevan työntekijöiden ja työnantajien yhteisen edun mukaista. Kilpailluilla markkinoilla yritysten tuli olla tehokkaita selvitäkseen, eikä esimerkiksi edustuksellinen demokratia sopinut luontevasti tähän tavoitteeseen. Liike-elämän edustajien mukaan johtajien päätösvallan säilyttäminen oli välttämätöntä. Toisinaan he argumentoivat, että demokratia ei sopinut yrityksiin, koska tehokkuus ei ollut äänestys- vaan ammattitaitokysymys.

1970- ja 1980-luvuilla Suomessa ja Ruotsissa toteutettiin useita poliittisia reformeja taloudellisen demokratian nimissä. Niiden tulokset olivat lopulta lähempänä liike-elämän ja porvaripuolueiden kuin vasemmiston ajatuksia. Vaatimukset työntekijöiden vallasta yrityksissä muuttuivat yhteistoiminnaksi tai "myötämääräämiseksi", joilla tarkoitettiin työntekijöiden kuulemista mutta lopullisen päätösvallan jättämistä työnantajille. Ajatus työntekijöistä yritysten omistajina muuttui yritysten tarjoamaksi yksilölliseksi osakesäästämiseksi esimerkiksi henkilöstörahastojen kautta, mikä ei merkinnyt vallan jakamista uudelleen. Suomessa rahastojärjestelmästä tuli vapaaehtoinen, ja Ruotsissa ammattiliittojen radikaali vaatimus palkansaajarahastoista, jotka voisivat saada määräysvallan yrityksissä, muokattiin maltilliseen osakesäästämisen muotoon sosiaalidemokraattien epäröinnin sekä työnantajien ja porvaripuolueiden ankaran vastarinnan myötä.

\section{KOHDATUT DILEMMAT SELITTÄVÄT KÄSITTEELLISTÄ MUUTOSTA}

Yhteistoimintalainsäädännön ja uusien rahastojen perustamisen jälkeen keskustelu taloudellisesta demokratiasta vaimeni vähitellen Suomessa ja Ruotsissa. Ajatus talouden demokraattisesta ohjailusta oli jo kyseenalaistunut poliitikkojen kohdatessa 1970-luvun talouskriisit, joiden myötä 
he tekivät uusia tulkintoja todellisuudesta. Sen jälkeen kun Bretton Woods -valuuttajärjestelmästä oli luovuttu ja vuoden 1973 öljykriisi oli ravistellut maailmantaloutta, myös Suomi ja Ruotsi kärsivät samanaikaisesti korkeasta inflaatiosta ja työttömyydestä. Valtion budjetin ja vaihtotaseen vajeet alkoivat kasvaa. Päättäjät etenkin Ruotsissa vastasivat ongelmiin aluksi keynesiläisillä elvytys- ja työllistämistoimilla, mutta kriisin jatkuessa sosiaalidemokraatit ensin Suomessa ja myöhemmin Ruotsissa omaksuivat talouskuriin, inflaation hillitsemiseen ja yksityisen sektorin kilpailukyvyn parantamiseen tähtäävän politiikan (Andersson 2006; Outinen 2015).

Uutta poliittista linjaa on usein kutsuttu kolmannen tien sosiaalidemokratiaksi. Sitä pidetään tavallisesti selvänä siirtymänä oikealle, ja se tarkoittikin pitkälti talouskehityksen ohjailun ja suunnittelun hylkäämistä. Tämä oli ollut sosiaalidemokraateille taloudellisen demokratian käsitteen keskeinen elementti.

Vastoin vuonna 1975 antamaansa julkilausumaa Suomen sosiaalidemokraatit hyväksyivät viimeistään vuodesta 1977 eteenpäin markkinoiden kasvavan roolin talouden ohjausmekanismina ja korostivat yksityisen sektorin roolia talouskasvun moottorina (Outinen 2015). Vanhoja talouden sääntelyn keinoja kevennettiin tai hylättiin kokonaan, kuten useimmissa muissakin länsimaissa. Sosiaalidemokraattien johtamat hallitukset Suomessa ja Ruotsissa vapauttivat pääomaliikkeitä, luotonantoa ja korkotasoa 1980-luvun aikana (Streeck 2015; Blyth 2002). Demokratian sijasta uudistuksia perusteltiin kilpailukyvyn, talouskasvun ja siten myös yhteisen hyvän takaajina.

Politiikantutkija Mark Bevir (1999) on selittänyt aatteellista ja käsitteellistä muutosta dilemmoilla, joita menneisyyden toimijat ovat kohdanneet. Dilemmat voivat olla käsityksiä muuttuvista olosuhteista, kuten talouskriiseistä, jotka saavat toimijat kyseenalaistamaan omia uskomuksiaan. Tämä selitysmalli sopii hyvin taloudellisen demokratian tapaukseen. Sosiaalidemokraatit, joista oli tullut vastuullisia ja pragmaattisia valtionhoitajia Suomessa ja Ruotsissa, uskoivat, että globalisoituva kapitalismi loi kansallisvaltioille uusia rajoitteita ja välttämättömyyksiä. Suomen ja Ruotsin kaltaisten pienten maiden uskottiin olevan ulkoisten voimien armoilla. Suomen pääministeri Kalevi Sorsa julisti jo vuonna 1977 Korpilammen konferenssissa, että yhdentyvässä maailmassa Suomi joutui kilpailemaan itseään vahvempien kanssa näiden asettamilla ehdoilla.

Talouden taantuma sai julkisen velan kasvamaan ja pääoman vapaa liikkuvuus pakotti valtiot houkuttelemaan kansainvälisiä sijoituksia. Yleisesti tunnustetuksi viisaudeksi tuli, että kansallisista kahleistaan vapautettu pääoma etsisi helposti uusia investointikohteita, jos valtiot eivät keventäisi verotusta ja talouden sääntelyä. Omassa kontekstissaan tämä oli rationaalista päättelyä ja sopeutumista tilanteeseen, jonka suuret teollisuusmaat Yhdysvaltain johdolla olivat päätöksillään luoneet.

Kapitalismin puolustajat argumentoivat usein, että pääoman vapaus kasvattaa myös yksilönvapautta. Liberaali kapitalismi on kuitenkin tuottanut uudenlaista keskitettyä hallintaa. 1970-luvulta lähtien taloudellista valtaa on siirretty paitsi valtioilta markkinoille ja pääoman omistajille, myös demokraattisesti valituilta poliitikoilta asiantuntijoille keskuspankeissa ja valtiovarainministeriöissä. Näiden tehtävänä on pitää yllä markkinatalouden sääntökehikkoa budjettirajoitusten ja inflaatiotavoitteiden kaltaisilla työkaluilla. Sääntöihin ja asiantuntijuuteen perustuva vallankäyttö on varsin kaukana aiemmasta tavoitteesta jakaa taloudellista valtaa tavallisille kansalaisille. 
Näissä olosuhteissa pohjoismaiset sosiaalidemokraatit jättivät tavoitteen talouden demokratisoimisesta syrjään ja keskittyivät suojelemaan hyvinvointivaltiota globaalissa kilpailutaloudessa. Tämä puolustuksellinen suuntaus vakiintui entisestään, kun reaalisosialismin romahdus sai kapitalismin vaikuttamaan ainoalta toimivalta talousjärjestelmältä.

Ruotsissa poliitikot puhuvat edelleen taloudellisesta demokratiasta, mutta käsite on lähes tyhjentynyt kaikesta sisällöstä, eikä enää osoita tietä uuteen talous- ja yhteiskuntajärjestelmään tai edes merkittäviin reformeihin. Taloutta ja yrityksiä ei ole pidetty erityisen relevantteina demokratisoimisen kohteina sitten 1980-luvun lopun. Demokratisoinnin käsitteen viittausala on kaventunut selvästi: uusien elämänalojen politisoinnin sijaan se on rajoittunut alueisiin, joita jo pidetään poliittisina tai julkisina, kuten julkishallinto, julkiset palvelut, puolueet ja ammattiliitot. Kaikkia näitä on ainakin 1960-luvulta asti syytetty byrokraattisuudesta ja etäisyydestä tavallisiin kansalaisiin, minkä vuoksi niiden katsotaan kaipaavan demokratisointia.

Porvaripuolueet ja liike-elämä Suomessa ja Ruotsissa vähensivät puhettaan taloudellisesta demokratiasta ja yritysdemokratiasta jo 1980-luvun alussa. Tämä oli tarkoituksellinen retorinen siirto, jolla pyrittiin erottamaan taloutta ja demokratiaa toisistaan. Tästä voi päätellä, että erityisesti liike-elämän aiemmat yritykset taloudellisen demokratian uudelleenmäärittelyyn olivat olleet pääasiassa reaktioita vasemmiston retoriikkaan ja vaatimuksiin. Liike-elämän ja oikeiston asema vahvistui 1970-luvun aikana paitsi talouskehityksen myös merkittävän lobbaustoiminnan ansiosta. Kun vapaita markkinoita korostava ajattelu sai kaikupohjaa talouskriisin aikana ja kapitalismin kritiikki heikkeni, demokratiakäsitteet eivät vaikuttaneet enää yhtä tarpeellisilta liike-elämän ja oikeiston poliittisten tavoitteiden legitimoimiseen. Näkemyksestä, jonka mukaan politiikka ja talous olivat erillisiä elämänaloja, oli tullut varteenotettavampi. Tässä maailmankuvassa politiikassa on kyse kollektiivisten, arvoihin tai mielipiteisiin perustuvien päätösten tekemisestä, kun taas talouden saralla etsitään objektiivisesti katsoen tehokkaimpia toimintatapoja.

\section{KAPITALISMIN JA DEMOKRATIAN RISTIRIIDAT}

1970-luvulla alkanut poliittinen, taloudellinen ja ideologinen murros on näennäisen helppo tapa selittää, miksi taloudellisen demokratian käsite on kadonnut poliittisesta kielestä. Käsite ei sopinut maailmaan, jossa talouden globalisaatio ja vapaat markkinat valtasivat alaa ja uusliberaalit ajattelijat perustelivat niiden hyötyjä. Aiempi tutkimus ei kuitenkaan ole analysoinut kovin tarkasti niitä käsitteellisiä elementtejä, jotka tekevät taloudellisen demokratian ja vapaan kapitalismin ihanteiden yhdistämisestä vaikeaa.

Demokratia on ollut erittäin kiistanalainen käsite läpi sen historian, mutta sillä on ollut myös varsin pysyviä merkityskomponentteja, kuten kansanvalta, poliittinen tasa-arvo ja kollektiivinen päätöksenteko. Jännite demokratian ja yksilönvapauden välillä on niin ikään tullut toistuvasti esille.

Uusliberalismi on toinen kiistelty käsite, joka voidaan kuitenkin liittää yleisnimityksenä liberalismia 1900-luvulla uudistaneisiin ajattelijoihin (Olsen 2019). Tunnetuimpia uusliberaaleja, kuten Friedrich von Hayekia ja Milton Friedmania, on toisinaan syytetty demokratiavastaisuudesta. Tulkinnalle on perusteensa, sillä Hayek ja Friedman korostivat yksilönvapautta kollektiivisen 
päätöksenteon sijaan. He tahtoivat rajoittaa demokratiaa vahvoilla perustuslaeilla, jotta kansanvalta ei alkaisi puuttua yksilöiden ja markkinoiden vapauteen (Slobodian 2018).

Vaikka Hayek oli skeptinen talouden rationaalisen hallinnan suhteen ja siksi halusi, että talouteen puututaan mahdollisimman vähän, monet uusliberaalit ovat rajoittaneet demokratiaa määrittelemällä talouden politiikasta erilliseksi objektiivisen tiedon alueeksi. Tällainen epäpolitisointi näkyy monissa nykyisissä taloudellisen hallinnan instituutioissa, kuten itsenäisissä keskuspankeissa ja ylikansallisissa sopimuksissa, jotka rajoittavat talouspolitiikkaa (Streeck 2015). Niiden kautta asiantuntijat sanelevat kansalaisille taloudellisia välttämättömyyksiä jättäen vähän tilaa demokraattiselle politiikalle.

Taloudellisten välttämättömyyksien korostaminen on ollut tavallista liike-elämälle ja porvaripuolueille Suomessa ja Ruotsissa (Kettunen 2008). Ne laativat omat määritelmänsä taloudellisen demokratian kaltaisista käsitteistä, mutta ilmaisivat myös vahvoja varauksia demokratian soveltamisesta taloudellisissa instituutioissa. Talous esitettiin yksilöllisten valintojen ja objektiivisen tiedon, ei kollektiivisten päätösten ja poliittisten mielipiteiden valtakuntana. Liike-elämällä ja porvaripuolueilla oli ongelmia käsitteellisten elementtien kanssa, jotka ovat lähes väistämättä läsnä demokratiasta puhuttaessa. Näihin kuuluvat kansan harjoittama valta ja johtajien vastuunalaisuus kansalaisille. Jos demokratiaa sovelletaan talouteen ja se ymmärretään kansan tai työntekijöiden valtana, demokratia ajautuu ristiriitaan liberaalin kapitalismin historiallisten ydinelementtien kanssa, joihin kuuluu olennaisesti yksilön vapaus käyttää omaisuuttaan parhaaksi katsomallaan tavalla.

Talouden sfääriin sovellettuna demokratian käsite kantaa aina mukanaan mahdollisuutta immanenttiin kritiikkiin, joka perustuu demokratian historiallisiin merkityssisältöihin. Vaikka demokratia samaistettaisiin yksilönvapauteen, sopimusvapauteen ja kulutusvalintoihin, voivat valtaan, konfliktiin ja kollektiivisiin päätöksiin viittaavat merkityskerrostumat aina aktualisoitua: ihmiset voivat alkaa vaatia, että taloudellisen vallan tulisi perustua kansalaisuuteen tai työhön omistuksen ja asiantuntemuksen sijaan. Tästä syystä liike-elämä sekä keskusta- ja oikeistopuolueet ovat mieluummin vaienneet taloudellisesta demokratiasta kuin määritelleet käsitettä uudelleen omiin ideologioihinsa sopivaksi.

\section{GLOBAALIT ONGELMAT TEKEVÄT TALOUDESTA POLIITTISTA}

Tällä hetkellä taloudellisen demokratian käsite on edelleen marginaalissa, jonne se ajautui 1990-luvun alussa. Vaikka se esiintyy akateemisissa keskusteluissa ja joidenkin aktivistien parissa, käsitteeseen aiemmin liitetyt poliittiset tavoitteet ovat harvinaisia. Liike-elämän edustajat ja äänitorvet, jotka kannattavat kapitalismin uudistamista, ovat lähinnä ottaneet esille vanhan ajatuksen kaikkien sidosryhmien huomioimisesta. Tämän proaktiivisuuden taustalla lienee pyrkimys minimoida julkisen vallan puuttuminen liiketoimintaan. Yksityinen liike-elämä yrittää edelleen löytää keinoja nykyisen pääoman kasautumislogiikan säilyttämiseksi ja sen tekemisen hyväksyttäväksi kansalaisille panostamalla vapaaehtoisesti yhteiskunta- ja ympäristövastuuseen. On kuitenkin aiheellista pohtia, onko tämä riittävää kapitalismin uudistamista vai tulisiko demokraattisten yhteiskuntien jälleen kerran ottaa esiin kysymys talouden demokratisoimisesta. 
Viime vuosina keskustelut ilmastonmuutoksesta ja taloudellisesta eriarvoisuudesta ovat synnyttäneet ehdotuksia talousjärjestelmän uudistamisesta ja demokratian laajentamisesta. Uusimmassa kirjassaan Capital et idéologie taloustieteilijä Thomas Piketty (2019) ehdottaa muun muassa suurimpien omaisuuksien verottamista, vastikkeetonta pääomaa nuorille aikuisille ja 50 prosentin työntekijäedustusta yritysten hallintoon. Jos tällaiset ajatukset onnistuvat yli 30 vuoden tauon jälkeen innoittamaan merkittäviä poliittisia aloitteita ja liikkeitä, on hyvä tuntea myös niiden historiaa.

Menneissä keskusteluissa ja toteutuneissa malleissa taloudellisen demokratian ongelmina ovat olleet luisuminen keskitettyyn byrokratiaan, joka on jäykkää ja kansalaisille vierasta, tai pelkkään ruohonjuuritason osallistumiseen, joka ei tuota laajempaa muutosta. Pohjoismaiden sosiaalidemokraatit vaativat perinteisesti demokratiaa taloudellisen toiminnan kaikille tasoille, kansantalouden ohjailusta yritysten päätöksentekoon. Tämä on edelleen hyvä lähtökohta, mutta globaalin tason huomioimisen tarve nostaa uudistusten vaikeustasoa valtavasti.

Vaikeuksista huolimatta toimeen on ryhdyttävä, sillä ilmastonmuutos ja eriarvoisuus ovat jatkuvasti akuutimpia globaaleja ongelmia. Niiden myötä kasvaa tarve löytää uusia keinoja, jotka mahdollistavat ihmisten osallistumisen taloudellisten resurssien tuotantoa, käyttöä ja jakamista koskevaan päätöksentekoon. Taloudellisen demokratian kehittäminen tarkoittaisi toisin sanoen sitä, että kysyisimme entistä vahvemmin itseltämme ja toisiltamme, millainen talousjärjestelmä on demokraattinen, oikeudenmukainen ja ekologisesti kestävä.

\section{VIITTEET}

1. Kirjoitus perustuu 30.11.2019 Helsingin yliopistossa järjestetyn väitöstilaisuuden lectio praecursoria -esitelmään.

\section{LÄHTEET}

Andersson, Jenny. 2006. Between Growth and Security. Swedish Social Democracy from a Strong Society to a Third Way. Manchester: Manchester University Press.

Bevir, Mark. 1999. The Logic of the History of Ideas. Cambridge: Cambridge University Press.

Blyth, Mark. 2002. Great Transformations. Economic Ideas and Institutional Change in the Twentieth Century. Cambridge: Cambridge University Press. https://doi.org/10.1017/CBO9781139087230

Dunn, John. 2005. Setting the People Free. The Story of Democracy. Lontoo: Atlantic Books.

Financial times. 2019. FT sets the agenda with new brand platform. Financial Times 16.9.2019. https:// aboutus.ft.com/en-gb/announcements/ft-sets-the-agenda-with-new-brand-platform/. Viitattu 6.3.2020.

Friberg, Anna. 2012. Demokrati bortom politiken. En begreppshistorisk analys av demokratibegreppet inom Sveriges socialdemokratiska arbetareparti 1919-1939. Tukholma: Atlas.

Kettunen, Pauli. 2008. Globalisaatio ja kansallinen me. Kansallisen katseen historiallinen kritiikki. Tampere: Vastapaino. 
Kärrylä, Ilkka. 2019. The Contested Relationship of Democracy and the Economy. Debates on Economic and Industrial Democracy in Finland and Sweden, 1960s-1990s. Helsinki: Helsingin yliopisto, Valtiotieteellisen tiedekunnan julkaisuja 129.

Olsen, Niklas. 2019. The Sovereign Consumer. A New Intellectual History of Neoliberalism. Cham: Palgrave Macmillan. DOI 10.1007/978-3-319-89584-0

Outinen, Sami. 2015. Sosiaalidemokraattien tie talouden ohjailusta markkinareaktioiden ennakointiin. Työllisyys sosiaalidemokraattien politiikassa Suomessa 1975-1998. Helsinki: Into kustannus.

Slobodian, Quinn. 2018. Globalists: The End of Empire and the Birth of Neoliberalism. Cambridge, Massachusetts: Harvard University Press.

Streeck, Wolfgang. 2015. Ostettua aikaa. Demokraattisen kapitalismin lykätty kriisi. Tampere: Vastapaino. Piketty, Thomas. 2019. Capital et idéologie. Pariisi: Éditions du Seuil.

Pöytäkirja Suomen Sosialidemokraattisen puolueen XXX puoluekokouksesta 1975.

\section{KIRJOITTAJATIEDOT}

\section{ILKKA KÄRRYLÄ}

VTT, tutkijatohtori

Valtiotieteellinen tiedekunta

Helsingin yliopisto

ilkka.karryla@helsinki.fi 